Case Report

\title{
Retroauricular Advancement Flap In Single Stage Auricular Defect Reconstruction
}

\author{
Mirta H. Reksodiputro*, Trimartani Koento, Dwi W. Manunggal \\ Department of Otorhinolaryngology-Head and Neck Surgery, \\ Faculty of Medicine Universitas Indonesia - dr. Cipto Mangunkusumo Hospital, Jakarta \\ *Corresponding author: citamirta@yahoo.com \\ Received 24 April 2021; Accepted 20 July 2021 \\ http://doi.org/10.23886/ejki.9.54.145
}

\begin{abstract}
Auricular defects must be treated early and properly because they may interfere with facial symmetry. Retroauricular skin is an ideal flap source for a non-reduction reconstruction procedure of the upper, middle, and lower auricular defects. Auricular reconstruction aims to achieve good anthropometric and aesthetic ear unit. The purpose of this case report is to present a reconstruction of auricular defects using the rectroauricular flap that results in a favorable aesthetic and normal anthropometric dimensions of the auricular. We report a case of auricular defect caused by post-excision of keloid located in the helical and antithetical area of the middle third of the right auricular, using a retroauricular flap. Normal values of the auricular's anthropometric measurements were achieved, followed by a complete aesthetic ear unit. Retroauricular flaps are suitable for reconstructing partial auricle defects in the helical rim, temporal area, and conchae.

Keywords: auricular defect, retroauricular flap, aesthetic ear unit, auricular anthropometry.
\end{abstract}

\section{Jabir Retroaurikular untuk Rekonstruksi Defek Telinga}

\begin{abstract}
Abstrak
Daun telinga berperan penting pada simetri wajah sehingga defek di daun telinga harus ditangani dengan baik sejak dini. Kulit retroaurikular merupakan sumber jabir ideal untuk rekonstruksi tanpa reduksi pada defek daun telinga bagian atas, tengah, dan bawah. Rekonstruksi daun telinga bertujuan untuk mendapatkan hasil yang baik secara antropometri dan estetika unit telinga. Tujuan laporan kasus ini adalah menunjukkan hasil yang baik berdasarkan unit telinga estetik dan dimensi normal antropometri pada rekonstruksi defek daun telinga menggunakan jabir rektroaurikular. Dilaporkan satu kasus defek telinga pasca-eksisi keloid, di area heliks dan antiheliks sepertiga tengah daun telinga kanan, menggunakan jabir retroaurikular. Didapatkan nilai normal pada pengukuran antropometri telinga dan kelengkapan estetika unit telinga. Jabir retroaurikular baik untuk rekonstruksi defek telinga parsial di lengkung heliks, area temporal, dan konka.
\end{abstract}

Kata kunci: defek aurikular, jabir retroaurikular, unit telinga estetik, antropometri daun telinga. 


\section{Introduction}

Auricular defects are a major aesthetic problem. If it is not managed properly at the beginning, it may require some corrective procedures in the future which can cause severe psychological distress to the patient. There are various reconstructive procedures which currently available for auricular defects. The choice of defect reconstruction should always be made according to anatomical location, size, shape and depth of the defect. ${ }^{1,2}$

Several reconstructions are similar for upper and middle third of auricle and in part also for the lower auricle. According to Weerda, ${ }^{3}$ auricular defect was divided into 3 regions (upper, middle, and lower) and the reconstruction of auricular defect could be with or without auricular reduction. The methods of reconstruction with auricular reduction are reconstruction of wedge-shaped defects with Burrow's triangles, Antia Buch technique, and wedge-shaped composite graft from the contralateral ear. The recommended methods of reconstruction without auricular reduction are advancement and transposition flaps of the retroauricular region. ${ }^{4}$ Retroauricular skin is an ideal skin flap bank for reconstruction of the anterior surface, the lobule, or occasionally the free margin in terms of the color, texture, relatively-relaxed and well-vascularized structure. ${ }^{5}$ In this report, authors presented a case of auricular keloid caused by traffic injury with one stage of reconstruction using retroauricular advancement flap technique at $\mathrm{dr}$. Cipto Mangunkusumo General Hospital, Jakarta.

The incision of all reconstructive procedures of auricle should be made along their borders. We can ensure successful ear reconstruction with satisfactory aesthetic results by paying attention to the manipulation and availability of well-vascularized functioning tissue such as decreased traction at the reconstruction site to ensure tissue vitality, aesthetic considerations, and patient expectations. ${ }^{1}$

\section{Case Illustration}

A 23-year-old male had right ear injury due to traffic accident in 2009 and the skin suture was done at emergency department of private hospital. Patient with a history of slow growing swelling at the sutured region of right ear which started in 2010 and had the excision done in 2017 at previous hospital. Two years after excision, the swelling reoccurred at the same location (Figure 1). Patient stated that current swelling is bigger and growing faster than the previous one. The complaint of profound keloid was associated with itchiness and decrease in aesthetic qualities. Physical examination revealed that the swelling was firm, non-tender, dumbbell-shaped, double pedunculated, measuring $1 \mathrm{~cm}$ in diameter each, present on one third medial part of the helix. All aesthetic ear unit were completely present.



Figure 1. Pre-operative Auricular Keloid. Dumbbellshaped,double pedunculated, measuring $1 \mathrm{~cm}$ in diameter each, on one third medial part of the helix.

The patient was submitted to the operating room for keloid excision under general anesthesia. After keloid excision, some parts of the skin of helix were missing. There was no involvement of cartilage. The size of the helical defect after keloid excision is 2 $\mathrm{cm}$ in diameter and classified as medium size. The primary closure may not be applicable in this case, because it can result in the loss of helical structure. Therefore, the most suitable technique for this auricular defect is retroauricular flap. Incision was made at retroauricular area, undermined until the size suits to the recipient site. Tension of the flap could influence the angle of auricle to the mastoid, so that undermining should be posteriorly made as far as possible. Some of retroauricular skin were elevated to form a skin flap and advanced to cover auricular defects anteriorly. The skin was sutured appositionally with multiple interrupted 5-0 prolene (Figure 2). The treatment followed by intralesion triamcinolone injection directly after surgery. The sutures were removed on post-operative day 7 and there were no sign of inflammation, ischemia, or skin necrosis. The patient got intralesion injection of triamcinolone every 4 weeks routinely for 6 months. 




A

B

Figure 2. During Surgery. A. Flap was created posteriorly until defect was covered. B. There was no tension and auricle did not pull posteriorl

On the 12-month follow up, according to ear anthropometry, the distance between mastoid to helical rim in this patient is $2 \mathrm{~cm}$ on both ears (normal range 1-2 cm), the concho-mastoid angle is $21^{\circ}$ (right) and $24^{\circ}$ (left) (normal range $21-25^{\circ}$ )
(Figure 3). Aesthetic ear unit was complete and there was no recurrent swelling (Figure 4). The reconstruction site has an excellent healing, and the patient was adequately satisfied with the final results of the reconstruction.

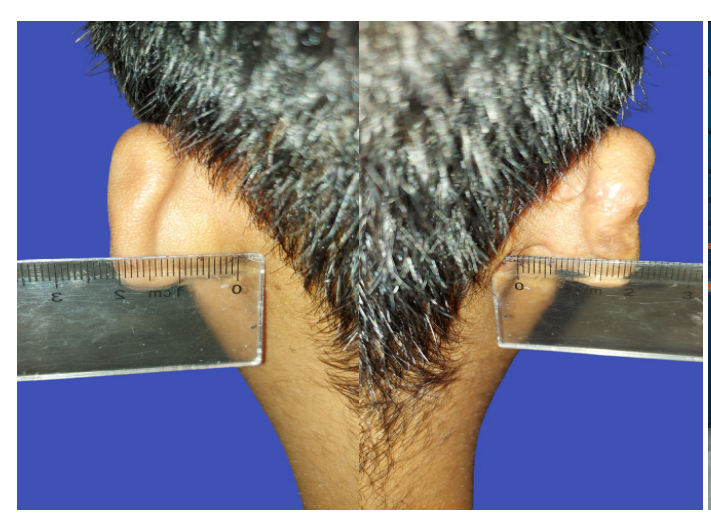

A

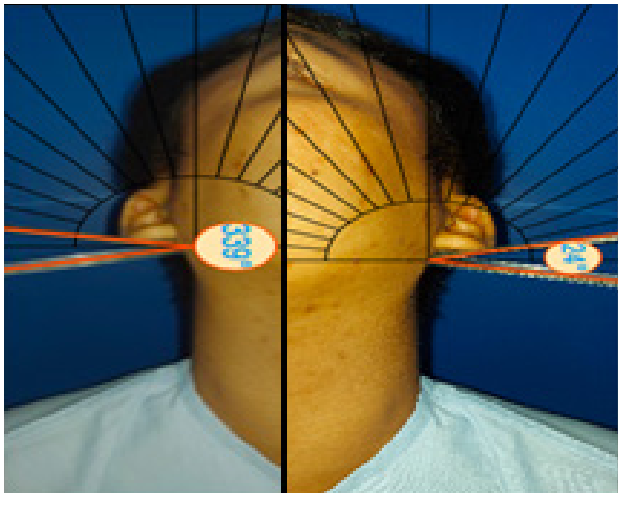

B

Figure 3. Twelve-Month Follow Up Normal Dimension of Anthropometric Measurement, A. Posterior view, distance between mastoid and helical rim $(2 \mathrm{~cm})$; B. Basal view, both concho-mastoid angle not differ much significantly, $21^{\circ}$ (right), $24^{\circ}$ (left)

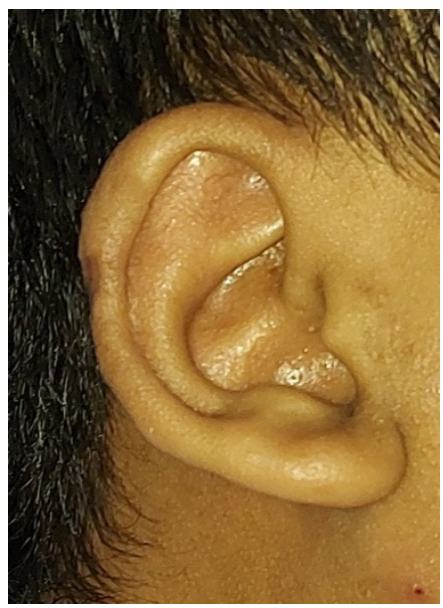

Figure 4. Twelve-Month Follow up.

The result shows complete aesthetic ear unit and no auricle reduction 


\section{Discussion}

The aesthetic ear units is nine parts of auricle that should be present in normal ear. They include helix, antihelix, scaphoid fossa, lobule, tragus, antitragus, triangular fossa, and concha subunits (Figure 5).6,7
In this case, aesthetic ear unit was completely shown and there was no secondary defect on helix and antihelix region post reconstruction using retroauricular advancement flap.



Figure 5. Aesthetic Ear Unit Includes Helix, Antihelix, Scaphoid Fossa, Lobule, Tragus, Antitragus, Triangular Fossa, and Concha Subunits ${ }^{6}$

The cartilaginous rim separates the helical subunit from the lobe subunit. ${ }^{6,7}$ Based on anthropometric measurement of the external ear, average length of adult ear is 55 to $65 \mathrm{~mm}$ and the width is approximately $55 \%$ of its length. The most superior point of the ear match with the level of the superior tarsal crease, and the most inferior point of the lobule align with the subnasale level. The helical rim elevates 1 to $2 \mathrm{~cm}$ from the scalp with the angle of elevation averaging 21 to 25 degrees. The long axis of the ear is tilted posteriorly at an angle of approximately 20 degrees from the vertical line (Figure 6). ${ }^{4}$ In this case, the post-reconstruction outcome has a normal anthropometric dimension of the auricular in the distance between the mastoid to the helical rim and concho-mastoid angle.


Figure 6. Anthropometric Measurement of The External Ear. A. Axis of the ear, B. Basal view of conchomastoid angle ${ }^{4}$

The human ear is an important part of the facial features. Missing of tissue exceeding one-fourth of the vertical auricular size will make aesthetic disfigurement requiring reconstructive surgery. The arterial supply of the auricle from branches of the posterior auricular artery (PAA) and the superficial temporal artery is the anatomical basis for auricular reconstructive surgery. Retroauricular artery perforator-based island flaps are considered practical regional flaps for repairing defects of the helical rim, temporal area, and concha. The blood supply of the retroauricular skin and fascia (from the posterior auricular artery) involves an area (angiosome) extending between the helical insertion, external auditory canal, and mastoid process that allows safe preparation of PAA-based fasciocutaneous flaps in 
this area ${ }^{8,9}$ According to Pickrell et al, ${ }^{4}$ the size and position of the auricular defect classified as medium size middle-third defects of helix $(1.5-2.5 \mathrm{~cm})$ and it can be reconstructed with a two-stage posteriorly based retroauricular flap.

Retroauricular flap is recommended for wide defects with cartilage preservation. After the design, preparation, and suture of the retroauricular flap into the defect, the ear is pinned back to avoid damage of the flap by tension/traction. Four weeks later, after weekly conditioning of the flap pedicle, the pedicle is divided, and the ear is detached from the retroauricular skin. This avoids auricular miniaturization, which occurs with other reconstruction techniques. Furthermore, the resulting scar is easily concealed behind the ear and the skin color and texture is a good match. One disadvantage is that it is a two-step procedure. Another disadvantage is that such flaps, even if they do not contract, may not solve the issue of auricular instability of the cartilaginous framework. The importance of leaving the flap for at least two weeks before dividing and detaching it from the retroauricular skin is for adequate collateral revascularization, which is essential in preventing flap loss. ${ }^{1,4,5}$

According to study of Worley et $\mathrm{al}^{10}$ and Dessy et al, ${ }^{11}$ retroauricular flap are recommended for auricular defect reconstruction surgery since it has good aesthetic outcome and no complication found in the patients. The study also explains the superiority of retroauricular flap over FTSG. Worley et $\mathrm{al}^{10}$ stated that further advantage of flaps over FTSG occurs when there is cartilage exposed without perichondrium, FTSG have reduced chance of survival. FTSG is best option for the small to medium size of the defect with intact perichondrium. Many of the transposition flaps or island pedicle can be enlarged to suit larger defects. ${ }^{10,11}$ Although these two studies have low validity, due to limited literature they are the best studies that can be used as a consideration for the selection of a retroauricular flap over FTSG for auricular defect reconstruction procedures.

In our case, the patient did not require second surgery to detach ear from the retroauricular skin. We made advancement flap by undermining until the size of the flap could cover the defect and ensuring that the flap can be adapted to the defect without tension. The retroauricular skin perfectly matches the post- auricular surface close to the defect in terms of color and texture. We did intralesion injection of triamcinolone right after suturing, and then repeat every 4 weeks for 6 months. Effects of corticosteroids are due primarily to their suppressive effects on the wound inflammation and secondarily to the reduction of collagen and glycosaminoglycan synthesis, inhibition of fibroblast growth, as well as enhanced collagen and fibroblast degeneration. Intralesion injection of triamcinolone acetonide 10$40 \mathrm{mg} / \mathrm{mL}$ routinely every 3-4 weeks for 6 months give a good result 8,9

\section{Conclusion}

One stage retroauricular flap technique is an excellent alternative for the reconstruction of auricular defects. Consideration should always be made on preventing tension on the flaps so that the ear's position will stay within range of normal ear anthropometry and desirable aesthetic results.

\section{References}

1. Roosseno RRN, Primawati. The management of auricular defect using retroauricular flap. Int J Res Med Sci. 2020;8:1912-7

2. Crisan D, Schneider LA, Kastler S, Kochanek KS, Crisan M, Veit JA. Surgical management of skin cancer and trauma involving the middle third of the auricle. J Dtsch Dermatol Ges. 2018;1606:694-701. doi: 10.1111/ ddg.13544.

3. Weerda H, Burner FX. Surgery of auricle. Germany: Gerorg Thieme Verlag. 2007p.63-69.

4. Pickrell BB, Hughes CD, Maricevich RS. Partial ear defects. Semin Plast Surg. 2017;31:134-40. doi: 10.1055/s-0037-1603968.

5. Zhang YZ, Li YL, Yang C, Fang S, Fan H, Xing $X$. Reconstruction of postauricular defects using retroauricular artery perforator-based island flaps: anatomical study and clinical report. Medicine. 2016;95:e4853.. doi: 10.1097/MD.0000000000004853.

6. Siegert R, Magritz R. Otoplasty and auricle reconstruction. Facial Plast Surg. 2019;35:377-386. doi: 10.1055/s-0039-1693745.

7. Cubitt JJ, Chang LY, Liang D, Vandervord J, Marucci DD. Auricular reconstruction. J Paediatr Child Health. 2019;55:512-7. https://doi.org/10.1111/jpc.14444

8. Carswell L, Borger J. Hypertrophic scarring keloids. [Updated 2020 Jan 8]. Treasure Island (FL): StatPearls Publishing; 2020 Jan. Available from: https://www.ncbi.nlm.nih.gov/books/ NBK537058/

9. Sobec R, Dobreanu C, Podor L, Somtecuan A, Tichil I, Cosgarea M. Ear keloids: a review and update of treatment options. Clujul Medical. 2013;86:313-7.

10. Worley B, Cohen JL. Reconstruction of cutaneous defects of the ear using the post-auricular reservoir: a systematic review. J Drugs Dermatol. 2020;19:883-8. doi: 10.36849/JDD.2020.10.36849/JDD.2020.5106.

11. Dessy LA, Figus A, Fioramonti P, Mazzocchi M, Scuderi N. Reconstruction of anterior auricular conchal defect after malignancy excision: revolving door flap versus full thickness skin graft. J Plast Reconstr Aesthet Surg. 2010;63:746-52. doi: 10.1016/j.bjps.2009.01.073. 